\title{
Gas exchanges and growth of cotton cultivars under water salinity
}

\author{
André A. R. da Silva ${ }^{1}$, Luana L. de S. A. Veloso ${ }^{1}$, Ronaldo do Nascimento ${ }^{1}$, Elka C. S. Nascimento ${ }^{1}$, \\ Carlos V. de C. Bezerra ${ }^{1} \&$ Márcia C. de A. Pereira ${ }^{1}$ \\ ${ }^{1}$ Universidade Federal de Campina Grande/Centro de Tecnologia e Recursos Naturais/Programa de Pós-Graduação em Engenharia Agrícola. Campina
Grande, PB, Brasil. E-mail: andrealisson_cgpb@hotmail.com - ORCID: 0000-0001-9453-1192 (Corresponding author); luana_lucas_15@hotmail.com -
ORCID: 0000-0003-0537-7985; ronaldo@deag.ufcg.edu.br - ORCID: 0000-0002-5086-8532; elka_costa@hotmail.com - ORCID: 0000-0001-7202-6216;
ccastroagro@gmail.com - ORCID: 0000-0003-4940-9213; marcia.cris19@hotmail.com - ORCID: 0000-0001-5557-4317
}

\begin{abstract}
Indication of salt-tolerant cotton cultivars can make the agricultural exploitation with saline water irrigation feasible in the Brazilian semi-arid region. Thus, this study aimed to evaluate the gas exchanges and growth of cotton cultivars irrigated with saline water. The study was conducted in pots adapted as drainage lysimeters under greenhouse conditions, using a sandy loam Entisols as substrate. Treatments were distributed in completely randomized design, in $5 \times 2$ factorial arrangement, relative to five levels of irrigation water electrical conductivity - ECw $\left(1.5,3.0,4.5,6.0\right.$ and $\left.7.5 \mathrm{dS} \mathrm{m}^{-1}\right)$ and two cotton cultivars (BRS $368 \mathrm{RF}$ and BRS Safira). Increase in irrigation water salinity inhibits the vegetative growth and gas exchanges of the cotton cultivars BRS Safira and BRS 368 RF. Leaf area and instantaneous carboxylation efficiency are the most affected variables. Physiological and growth performance of the cultivar BRS Safira in response to water salinity was higher than that of BRS $368 \mathrm{RF}$.
\end{abstract}

Key words: Gossypium hirsutum L., tolerance, cultivar BRS Safira

\section{Trocas gasosas e crescimento de cultivares de algodoeiro sob salinidade da água}

RESUMO: A indicação de cultivares de algodão tolerantes à salinidade pode viabilizar a exploração agrícola irrigada com água salina na região semiárida do Nordeste brasileiro. Deste modo, objetivou-se avaliar as trocas gasosas e o crescimento em cultivares de algodão irrigados com águas salinas. O estudo foi conduzido em vasos adaptados como lisímetros de drenagem sob condições de casa de vegetação, utilizando um Neossolo Regolítico Eutrófico de textura franco-arenosa como substrato. Os tratamentos foram distribuídos em delineamento inteiramente casualizado, em arranjo fatorial $5 \times 2$, relativo aos cinco níveis de condutividade elétrica da água de irrigação - CEa de 1,5; 3,0; 4,5; 6,0 e 7,5 dS m e duas cultivares de algodoeiro (BRS 368 RF e BRS Safira). O incremento da salinidade da água de irrigação inibe o crescimento vegetativo e as trocas gasosas do algodoeiro BRS Safira e BRS 368 RF, sendo a área foliar e eficiência instantânea da carboxilação as variáveis mais comprometidas. O desempenho fisiológico e de crescimento da cultivar BRS Safira submetida à salinidade da água superou o da BRS 368 RF.

Palavras-chave: Gossypium hirsutum L., tolerância, cultivar BRS Safira 


\section{INTRODUCTION}

Cotton cultivation has presented itself as an agricultural activity of considerable socioeconomic importance, especially for the Brazilian agribusiness, with an estimated production of $1,789 \mathrm{t} \mathrm{ha}^{-1}$ for the $2017 / 18$ season. In the Northeast region, particularly in the state of Bahia, cotton fields extend for 270.3 thousand hectares, with expected production of 641.8 thousand tons of seed and 427.8 thousand tons of lint (CONAB, 2018).

Despite being considered a salt-tolerant crop, its growth and production can be inhibited in Brazilian semi-arid regions, where salinity has increased due to the predominant geological conditions, rainfall volume and distribution, poor drainage and inadequate agricultural exploitation, transforming productive areas into areas with no agricultural function over time (Souza et al., 2017a).

When in excess, in both irrigation water and soil, salts can compromise the agricultural exploitation with economic viability, because they cause osmotic, toxic and nutritional effects, limiting plant growth and production, besides leading to degradation in soil physical structure when the concentration of adsorbed sodium prevails over those of other cations (Tavares Filho et al., 2012). Nevertheless, the intensity of the damaging effects of salinity on plants depends on other factors, such as species, cultivar, type of salts, intensity and duration of rootsoil contact, crop and irrigation managements, edaphoclimatic conditions and fertilization (Santos et al., 2016).

Research aiming to identify salt-tolerant cultivars is important, especially for agricultural exploitation in semi-arid regions. In this context, this study aimed to evaluate the gas exchanges and growth of two cotton cultivars irrigated with saline water.

\section{Materal AND Methods}

The study was carried out from November 2017 to March 2018 , in plastic pots adapted as drainage lysimeters under greenhouse conditions at the Center of Technology and Natural Resources of the Federal University of Campina Grande, in the municipality of Campina Grande, Paraiba state, Brazil, in the 'Agreste Paraibano' mesoregion, situated by the geographic coordinates $7^{\circ} 15^{\prime} 18^{\prime \prime} \mathrm{S}, 35^{\circ} 52^{\prime} 28^{\prime \prime} \mathrm{W}$ and altitude of $550 \mathrm{~m}$.

Treatments resulted from the combination between five levels of irrigation water electrical conductivity - ECw (1.5, 3.0, 4.5, 6.0 and $7.5 \mathrm{dS} \mathrm{m}^{-1}$ ) and two cotton cultivars (BRS 368 $\mathrm{RF}$ and BRS Safira), distributed in a completely randomized design in $2 \times 5$ factorial arrangement, with four replicates.

The different levels of irrigation water electrical conductivity were established based on the salinity threshold of the cotton crop, $5.1 \mathrm{dS} \mathrm{m}^{-1}$ in the irrigation water (Souza et al., 2017a), and prepared by adding sodium chloride $(\mathrm{NaCl})$ in water from the local supply system $\left(\mathrm{EC}=0.8 \mathrm{dS} \mathrm{m}^{-1}\right)$ using the relationship between ECw and concentration of salts $\left(\mathrm{mmol}_{c} \mathrm{~L}^{-1}=10^{\star} \mathrm{ECw}\right.$ dS $\mathrm{m}^{-1}$ ) recommended by Richards (1954). $\mathrm{NaCl}$ was used because it is the salt present at highest concentration in water sources of the semi-arid region (Medeiros, 1992) and because it causes more significant damage to crops.

Plants were grown in plastic pots filled with a $0.3 \mathrm{~kg}$ layer of crushed stone ( $\left.\mathrm{N}^{\circ} 0\right)$, covering the base of the lysimeter, and
$18 \mathrm{~kg}$ of a sandy loam Entisols collected in the $0-20 \mathrm{~cm}$ layer from the rural area of the municipality of Lagoa Seca, Paraiba state, Brazil, which was properly pounded to break up clods and sieved. Its physical-hydraulic and chemical characteristics were determined according to the methodologies proposed by Donagema et al. (2011): $\mathrm{Ca}^{2+}, \mathrm{Mg}^{2+}, \mathrm{Na}^{+}, \mathrm{K}^{+}$and $\left(\mathrm{Al}^{3+}+\mathrm{H}^{+}\right)=$ $26.0 ; 36.6 ; 1.6 ; 2.2$ and $19.3 \mathrm{mmol}_{\mathrm{c}} \mathrm{kg}^{-1}$, respectively; $\mathrm{pH}$ (water $1: 2.5)=5.9$; ECse $\left(\mathrm{dS} \mathrm{m}^{-1}\right)=1.0$; organic matter $\left(\mathrm{g} \mathrm{dm}^{-3}\right)=$ 13.6; sand, silt and clay $=733,142$ and $125 \mathrm{~g} \mathrm{~kg}^{-1}$, respectively; bulk density $\left(\mathrm{kg} \mathrm{dm}^{-3}\right)=1.39$; moisture contents at pressures of 33.42 and $1519.5 \mathrm{kPa}=11.98$ and $4.32 \mathrm{dag} \mathrm{kg}^{-1}$, respectively.

After filling the pots, the soil was brought to field capacity and maintained at this level along the entire experiment with daily irrigations, applying in each pot the solutions corresponding to each treatment. The applied volume was estimated by water balance: water volume applied minus water volume drained in the previous irrigation, plus a leaching fraction of 0.15 , to avoid excessive accumulation of salts in the soil.

Sowing was carried out on November 10,2017, by planting four seeds in each pot at $1.5 \mathrm{~cm}$ depth. At 20 days after sowing (DAS), thinning was performed to leave only the most vigorous plantlet.

Fertilization with nitrogen $(\mathrm{N})$, phosphorus $(\mathrm{P})$ and potassium $(\mathrm{K})$ was applied as topdressing, as recommended by Novais et al. (1991); $4.0 \mathrm{~g}$ of urea, $4.5 \mathrm{~g}$ of potassium chloride and $10.8 \mathrm{~g}$ of monoammonium phosphate were applied and these amounts were equivalent to 100,150 and $300 \mathrm{mg} \mathrm{kg}^{-1}$ of soil of $\mathrm{N}, \mathrm{K}_{2} \mathrm{O}$ and $\mathrm{P}_{2} \mathrm{O}_{5}$, respectively. Phosphorus was applied before planting and potassium as topdressing through fertigation, split into two equal portions, at 45 day intervals, with the first application one day prior to sowing. Nitrogen fertilization was split into three portions, the first one applied 30 days after sowing, at a 30 day interval. Urea, monoammonium phosphate and potassium chloride were used as sources of nitrogen, phosphorus and potassium, respectively. In order to meet micronutrient requirements, cotton leaves were sprayed every 15 days with a solution of Ubyfol $\left(2.5 \mathrm{~g} \mathrm{~L}^{-1}\right)$ [(N (15\%); $\mathrm{P}_{2} \mathrm{O}_{5}$ (15\%); $\mathrm{K}_{2} \mathrm{O}$ (15\%); $\mathrm{Ca}(1 \%) ; \mathrm{Mg}(1.4 \%) ; \mathrm{S}(2.7 \%) ; \mathrm{Zn}(0.5 \%) ;$ B (0.05\%); Fe (0.5\%); Mn (0.05\%); Cu (0.5\%); Mo (0.02\%)], as recommended by the manufacturer.

The effects of different ECw levels on cotton cultivars were evaluated based on plant height (PH), stem diameter (SD), number of leaves (NL), leaf area (LA) and gas exchanges.

Cotton growth was evaluated at 20 and 50 DAS based on plant height, measured as the distance from the collar to the point of attachment of the apical meristem. SD was measured at $2 \mathrm{~cm}$ from the collar, and fully expanded leaves with minimum length of $2 \mathrm{~cm}$ were counted in each plant.

Leaf area $\left(\mathrm{cm}^{2}\right)$ was determined as recommended by Grimes \& Carter (1969), by measuring the midrib length of all leaves in the plant, according to Eq. 1.

$$
\mathrm{LA}=\sum(0.4322 \cdot \mathrm{P})^{2.3002}
$$

where:

LA - leaf area $\left(\mathrm{cm}^{2}\right)$; and,

$\mathrm{P} \quad$ - midrib length (m). 
At 50 DAS, gas exchanges were measured through stomatal conductance $\left(\mathrm{mol} \mathrm{H}_{2} \mathrm{O} \mathrm{m}^{-2} \mathrm{~s}^{-1}\right)$, transpiration $\left(\mathrm{mmol} \mathrm{H}_{2} \mathrm{O} \mathrm{m}^{-2} \mathrm{~s}^{-1}\right)$, $\mathrm{CO}_{2}$ assimilation rate $\left(\mu \mathrm{mol} \mathrm{m} \mathrm{m}^{-2} \mathrm{~s}^{-1}\right)$ internal $\mathrm{CO}_{2}$ concentration $\left(\mu \mathrm{mol} \mathrm{m} \mathrm{s}^{-1}\right)(\mathrm{Ci})$. These measurements were taken on the third leaf, counted from the apex, using the portable photosynthesis meter "LCPro+" from ADC BioScientific Ltda., at 9:00 A.M. These data were used to quantify the instantaneous water use efficiency (WUEi) (A/E) $\left[\left(\mu \mathrm{mol} \mathrm{m} \mathrm{m}^{-2} \mathrm{~s}^{-1}\right)\left(\mathrm{mol} \mathrm{H}_{2} \mathrm{O} \mathrm{m}^{-2} \mathrm{~s}^{-1}\right)^{-1}\right]$ and instantaneous carboxylation efficiency $(\mathrm{CEi})(\mathrm{A} / \mathrm{Ci})$ $\left[\left(\mu \mathrm{mol} \mathrm{m} \mathrm{m}^{-2}\right)\left(\mu \mathrm{mol} \mathrm{mol}{ }^{-1}\right)^{-1}\right]$ (Jaimez et al., 2005; Konrad et al., 2005).

The obtained data were subjected to analysis of variance separately for 20 and 50 DAS. In cases of significance, linear and quadratic polynomial regression analyses were carried out for the factor salinity, whereas Tukey test was conducted to compare the means of the factor cultivar at 0.05 probability level, using the statistical program SISVAR (Ferreira, 2014).

\section{Results AND Discussion}

Based on the summary of analysis of variance (Table 1), the levels of irrigation water salinity and the factor cultivar independently caused significant effects on transpiration (E), stomatal conductance (gs), $\mathrm{CO}_{2}$ assimilation rate (A) and instantaneous carboxylation efficiency (CEi). The interaction between the studied factors had no significant effect on any of the gas exchange variables analysed. Thus, it is possible to state that the two cotton cultivars have similar physiology in response to the different levels of salinity during their growth stage.

Transpiration (E) was linearly reduced by the increase in irrigation water electrical conductivity. According to the regression equation (Figure 1A), there was a linear decrease of $3.36 \%$ per unit increase in ECw. i.e. a reduction of $21.25 \%$ (1.34 $\mathrm{mmol} \mathrm{H}_{2} \mathrm{O} \mathrm{m}^{-2} \mathrm{~s}^{-1}$ ) in the $\mathrm{E}$ of plants irrigated using water of highest salinity $\left(7.5 \mathrm{dS} \mathrm{m}^{-1}\right)$ compared to those under the lowest level of salinity $\left(1.5 \mathrm{dS} \mathrm{m}^{-1}\right)$. The reduction in transpiration under salt stress conditions probably occurred due to partial stomatal closure, associated with osmotic and ionic toxicity effects which affect plant metabolism (Neves et al., 2009).

Considering the independent effect of cultivars (Figure 1B). BRS Safira had higher transpiration than BRS $368 \mathrm{RF}$, and it is possible to infer that transpiration was more damaged by salt stress in the cultivar BRS 368 RF than in BRS Safira, an effect usually attributed to partial stomatal closure, associated with the osmotic effect and ionic toxicity on plant metabolism. In these situations, there is a discrepancy between water absorption by roots and transpiration, so partial stomatal

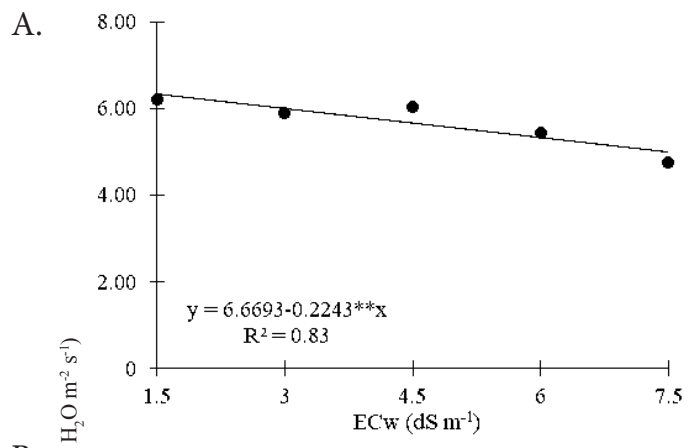

B.
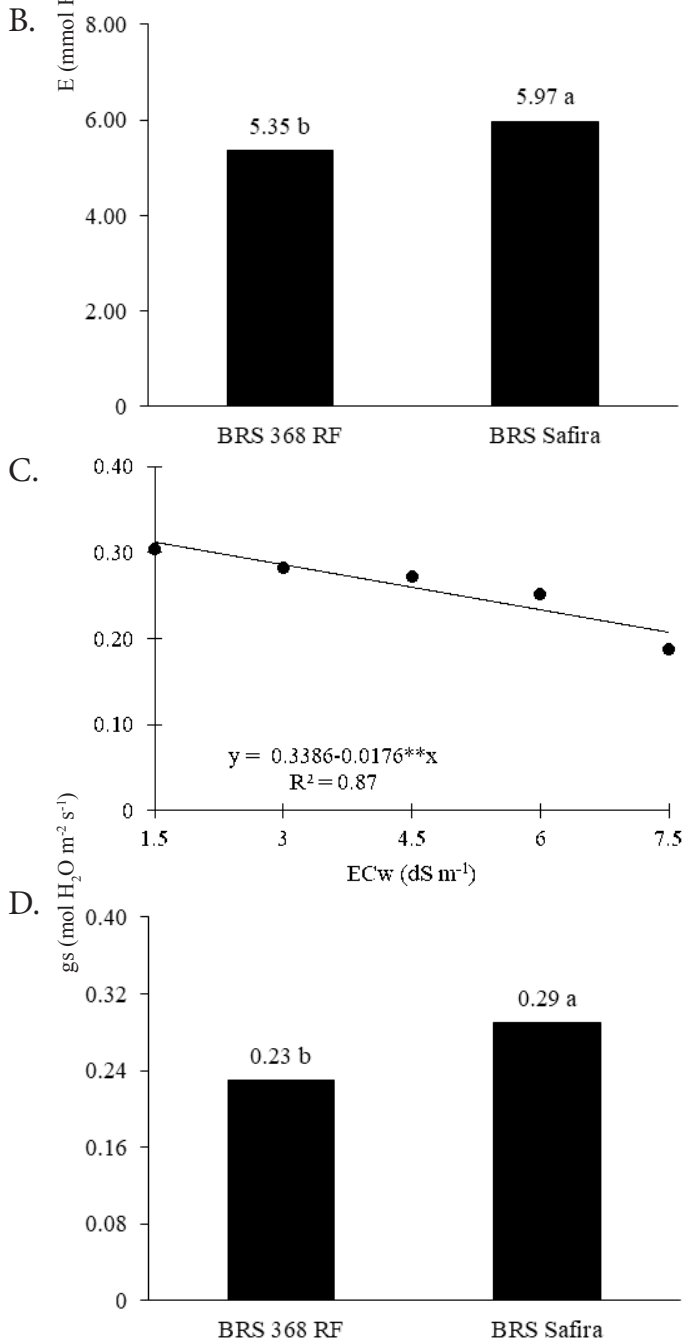

Means with the same letters indicate that the treatments do not differ by Tukey test, at $\mathrm{p}$ $<0.05$; ${ }^{* *}$ - Significant at $\mathrm{p} \leq 0.01$, by F test

Figure 1. Transpiration - E (A) and stomatal conductance - gs (C) as a function of irrigation water electrical conductivity ECw, and transpiration - E (B) and stomatal conductance - gs (D) of cotton as a function of the cultivars

Table 1. Summary of analysis of variance for intracellular $\mathrm{CO}_{2}$ concentration (Ci), transpiration (E), stomatal conductance (gs), $\mathrm{CO}_{2}$ assimilation rate (A), instantaneous water use efficiency (WUEi) and instantaneous carboxylation efficiency (CEi) of cotton cultivars irrigated with saline water, at 50 DAS

\begin{tabular}{|c|c|c|c|c|c|c|c|}
\hline \multirow{2}{*}{ Source of variation } & \multirow{2}{*}{ DF } & \multicolumn{6}{|c|}{ Mean squares } \\
\hline & & $\overline{C i}$ & $\bar{E}$ & gs & $\bar{A}$ & WUË & CEI \\
\hline Salinity level (SL) & 4 & $211.28^{\text {ns }}$ & $2.70^{* *}$ & $0.01^{* *}$ & $37.61^{* *}$ & $0.32^{\mathrm{ns}}$ & $0.001^{\star \star}$ \\
\hline Linear regression & 1 & $465.61^{\mathrm{ns}}$ & $9.05^{\star \star}$ & $0.05^{\star \star}$ & $140.34^{\star \star}$ & $1.24^{\mathrm{ns}}$ & $0.005^{\star \star}$ \\
\hline Quadratic regression & 1 & $353.58^{\mathrm{ns}}$ & $1.15^{\mathrm{ns}}$ & $0^{\text {ns }}$ & $5.35^{\mathrm{ns}}$ & $57 \times 10^{-6} \mathrm{~ns}$ & $14 \times 10^{-6} \mathrm{~ns}$ \\
\hline Cultivar & 1 & $1071.22^{\mathrm{ns}}$ & $3.85^{\star}$ & $0.03^{* *}$ & $77.53^{* *}$ & $0.71^{\star}$ & $0.002^{* *}$ \\
\hline Interaction (SL x Cultivar) & 4 & $1096.28^{\text {ns }}$ & $1.63^{\mathrm{ns}}$ & $0^{\text {ns }}$ & $11.23^{\text {ns }}$ & $0.56^{\mathrm{ns}}$ & $0.0003^{\text {ns }}$ \\
\hline Residue & 27 & & & & & & \\
\hline CV (\%) & & 10.34 & 14.26 & 23.52 & 17.64 & 16.07 & 21.99 \\
\hline
\end{tabular}

ns. " ". "Not significant. Significant at $\mathrm{p}<0.01$ and $\mathrm{p}<0.05$ probability, respectively, by F test; DF - Degrees of fredom 
closure was considered to be either a strategy to avoid excessive dehydration or a consequence of water imbalance in leaf epidermis (Lima et al., 2017b).

Unit increase in irrigation water electrical conductivity caused linear reduction of $5.20 \%$ in cotton stomatal conductance (Figure 1C). There was a reduction of $33.82 \%$ $\left(0.106 \mathrm{~mol} \mathrm{H}_{2} \mathrm{O} \mathrm{m}^{-2} \mathrm{~s}^{-1}\right)$ between plants irrigated using water of highest and lowest levels of salinity, respectively (7.5 and $\left.1.5 \mathrm{dS} \mathrm{m}^{-1}\right)$. Stomatal closure in plants leads to restriction to $\mathrm{CO}_{2}$ entry in leaf mesophyll cells, which may increase their susceptibility to photochemical damage, because salt stress negatively affects photosynthetic activity by altering parameters of the photosystem (Silva et al., 2010; Freire et al., 2014).

Stomatal conductance (gs) also differed significantly between the cotton cultivars. As shown in Figure 1D, BRS Safira with higher value of gs $\left(0.29 \mathrm{~mol} \mathrm{H}_{2} \mathrm{O} \mathrm{m}^{-2} \mathrm{~s}^{-1}\right)$ surpassed the cultivar BRS 368 RF by $26.1 \%$.

Net photosynthesis decreased linearly with the increase in irrigation water electrical conductivity. According to the regression equation (Figure 2A), highest capacity for $\mathrm{CO}_{2}$
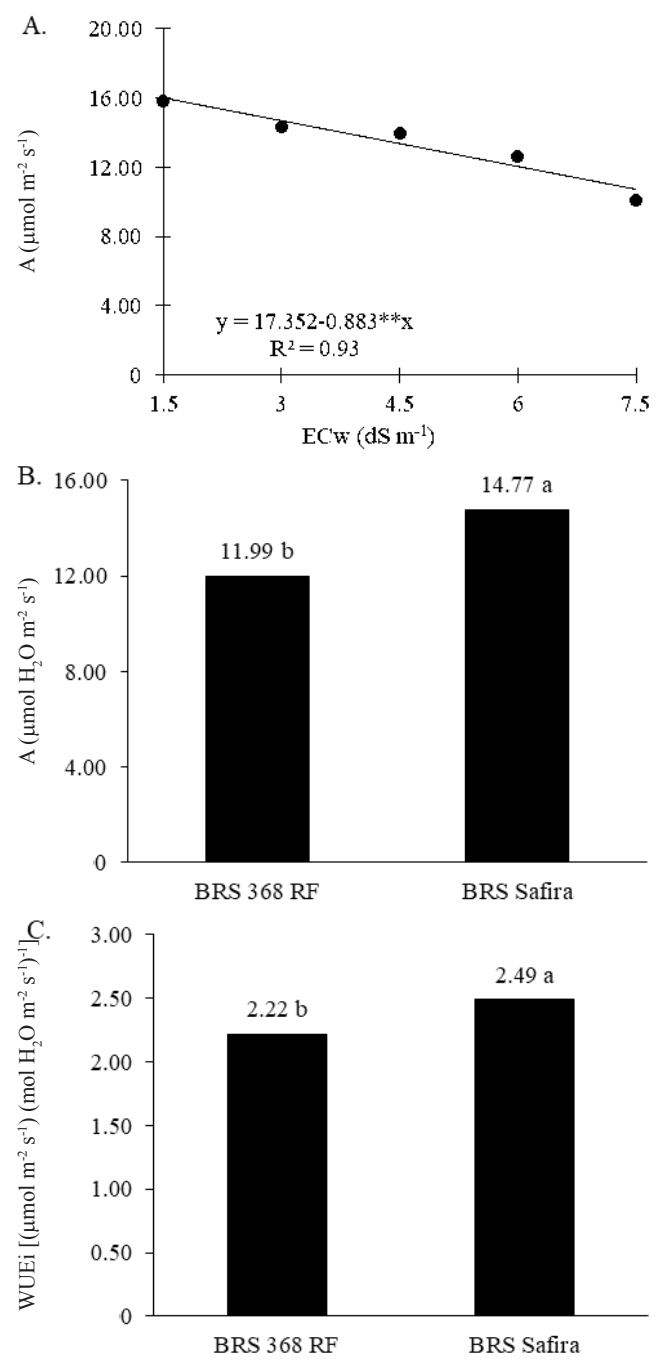

Means with the same letters indicate that the treatments do not differ by Tukey test, at $\mathrm{p}$ $<0.05$; ${ }^{* *}$ - Significant at $\mathrm{p} \leq 0.01$, by F test

Figure 2. Net photosynthesis (A) of cotton as a function of irrigation water electrical conductivity - ECw and net photosynthesis (B) and instantaneous water use efficiency WUEi (C) of the cotton cultivars BRS 368 RF and BRS Safira irrigated with different salinity water assimilation $\left(16.03 \mu \mathrm{mol} \mathrm{m} \mathrm{m}^{-2} \mathrm{~s}^{-1}\right)$ was found in cotton plants irrigated using water with electrical conductivity of $1.5 \mathrm{dS} \mathrm{m}^{-1}$. However, plants subjected to the highest level of salinity $\left(7.5 \mathrm{dS} \mathrm{m}^{-1}\right)$ showed a reduction of $33.05 \%\left(5.30 \mu \mathrm{mol} \mathrm{m} \mathrm{m}^{-2} \mathrm{~s}^{-1}\right)$ in comparison to those irrigated with the lowest level of salinity $\left(1.5 \mathrm{dS} \mathrm{m}^{-1}\right)$. Reduction of photosynthesis is usually a consequence of decrease in transpiration (Figure 1A) and stomatal conductance (Figure 1C). The low efficiency in the use of the $\mathrm{CO}_{2}$ which entered the cell may have been caused by the lower $\mathrm{CO}_{2}$ influx in the substomatal chamber for photosynthesis (Taiz et al., 2017).

As observed for transpiration and stomatal conductance, net photosynthesis (A) also differed significantly between the cotton cultivars, BRS Safira had the higher values of A $\left(14.77 \mu \mathrm{mol} \mathrm{m}{ }^{-2} \mathrm{~s}^{-1}\right)$, which corresponded to an increase of $23.1 \%$ compared to the cultivar BRS $368 \mathrm{RF}$ (Figure 2B).

Regarding instantaneous water use efficiency (WUEi), the means comparison test (Figure 2C) showed that the cultivar BRS Safira performed better than BRS 368 RF, which may be related to the higher values of net photosynthesis rate and transpiration recorded in BRS Safira. Thus, it can be inferred that BRS Safira plants were able to have higher $\mathrm{CO}_{2}$ fixation per unit of water lost.

According to the regression equation (Figure $3 \mathrm{~A}$ ), the instantaneous carboxylation efficiency (CEi) decreased by $6.01 \%$ per unit increase in irrigation water electrical conductivity, i.e., reduction of $39.64 \%$ in the CEi of plants irrigated using water of highest salinity $\left(7.5 \mathrm{dS} \mathrm{m}^{-1}\right)$ compared to those under the lowest level of salinity $\left(1.5 \mathrm{dS} \mathrm{m}^{-1}\right)$. According
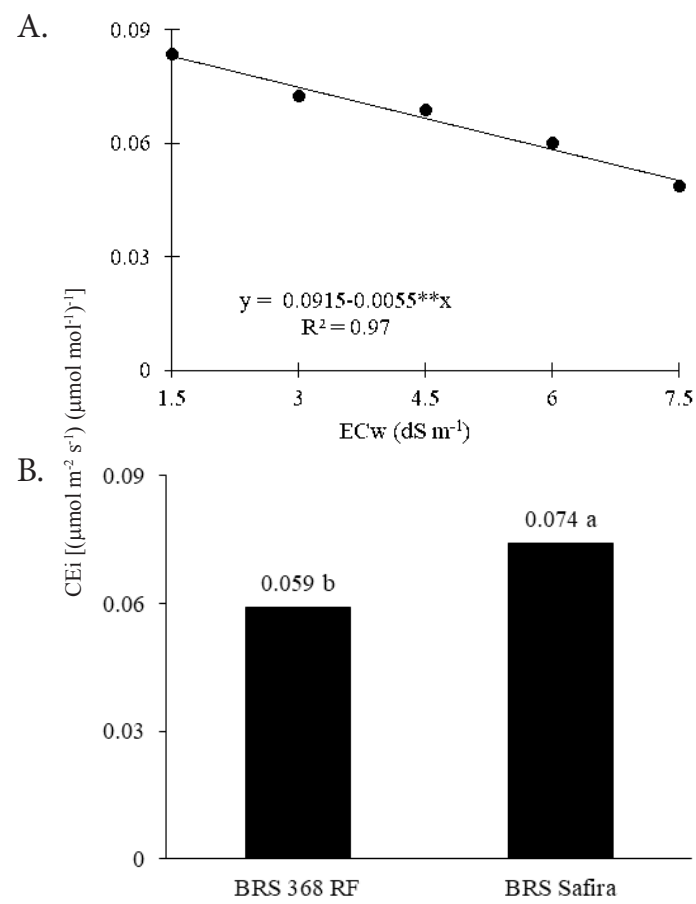

Means with the same letters indicate that the treatments not differ by Tukey test, at $\mathrm{p}<$ 0.05 ; ${ }^{* *}$ - Significant at $\mathrm{p} \leq 0.01$, by F test

Figure 3. Instantaneous carboxylation efficiency - CEi of cotton as a function of irrigation water electrical conductivity - ECW (A) and instantaneous carboxylation efficiency - CEi of the cotton cultivars BRS $368 \mathrm{RF}$ and BRS Safira (B) irrigated with different salinity water 
to Taiz et al. (2017), as the stress becomes more severe, the dehydration of mesophyll cells inhibits the photosynthetic capacity of the plant and hampers its metabolism, consequently compromising carboxylation efficiency. For Larcher (2006), such reduction in CEi is related to metabolic restrictions in the Calvin cycle, where the $\mathrm{C}$ received is not used in the carboxylation stage of mesophyll cells.

According to Figure 3B, the cultivar BRS Safira had higher instantaneous carboxylation efficiency $\left[\left(0.074\left(\mu \mathrm{mol} \mathrm{m} \mathrm{m}^{-2} \mathrm{~s}^{-1}\right)\right.\right.$ $\left.\left(\mu \mathrm{mol} \mathrm{mol}^{-1}\right)^{-1}\right]$ than BRS 368 RF $\left[0.059\left(\mu \mathrm{mol} \mathrm{m}^{-2} \mathrm{~s}^{-1}\right)\left(\mu \mathrm{mol} \mathrm{mol}^{-1}\right)^{-1}\right]$. Lower CEi in the cultivar BRS $368 \mathrm{RF}$ indicates that there were stomatal limitations in the $\mathrm{CO}_{2}$ photosynthetic assimilation, a very common process during prolonged periods of salt and water stresses. Nonetheless, the higher CEi observed in the cultivar BRS Safira can be a consequence of higher $\mathrm{CO}_{2}$ assimilation, compared to the $\mathrm{CO}_{2}$ found in the substomatal chamber, because if $\mathrm{Ci}$ increases due to the stomatal opening rate, the $\mathrm{A} / \mathrm{Ci}$ ratio also increases (Pereira, 2012; Sousa et al., 2012).

Water salinity levels had significant effect on plant height, stem diameter and number of leaves only at 50 DAS and on leaf area at 20 and 50 DAS (Table 2). The factor cultivar significantly affected only plant height at 20 and 50 DAS and leaf area at 20 DAS. For the interaction between salinity levels and cultivars, there was no significant effect on the studied variables at any time. According to these results, it can be stated that the longest time of exposure to salinity (50 DAS) has influenced the growth of cotton plants, since the number of variables with significant difference was higher at 50 DAS than at 20 DAS. According to Larcher (2006), the longer the time of exposure to the stress, the more severe the disorders caused by it and lower the chances of the plants to adjust to salinity.

Cotton growth in height and stem diameter (Figures $4 \mathrm{~A}$ and $\mathrm{B}$, respectively), as a function of water salinity, was respectively reduced by 6.79 and $5.32 \%$ per unit increase in irrigation water electrical conductivity. There were reductions of $24.07 \mathrm{~cm}$ and $2.57 \mathrm{~mm}$ in $\mathrm{PH}$ and $\mathrm{SD}$, respectively, in plants irrigated with $7.5 \mathrm{dS} \mathrm{m}^{-1}$ water, compared to those subjected to $1.5 \mathrm{dS} \mathrm{m}^{-1}$. These reductions result from excess salts in the root zone, causing deleterious effect on plant growth, because the excess of salts restricts the turgor of expanding tissues (Lima et al., 2017a). The results corroborate those presented by Souza et al. (2017b), who found that irrigation with saline water from $1.7 \mathrm{dS} \mathrm{m}^{-1}$ inhibited cotton growth and attributed this reduction to the osmotic effect, which can cause morphological and anatomical alterations in plants to the point of hampering water absorption and transpiration rate, affecting cell turgor and limiting plant growth.

The number of leaves at 50 DAS (Figure 4C) decreased by $7.79 \%$ per unit increase in ECw, which corresponds to a reduction of approximately 13 leaves between plants subjected to highest and lowest levels of salinity. The reduction of NL in cotton plants may be related to the mechanism of adaptation to salt stress, demonstrating that leaves are sensitive organs and their size and number decrease in the presence of high salt concentrations. Production of new leaves may also be limited and senescence may be increased due to the chloride absorbed by plants and accumulated in their leaves. These morphological alterations occur due to imbalances related to water, nutrients and hormones. As a result, these alterations lead to stomatal closure, reduction in transpiration and, consequently, decrease in the absorption of water and nutrients by plants, resulting in lower growth (Prisco et al., 2016).

According to the regression equations (Figures $4 \mathrm{D}$ and E), leaf area decreased by approximately $4.74 \%$ at 20 DAS and $10.09 \%$ at 50 DAS per unit increase in ECw. Thus, the greatest reduction in LA occurred after a longer time of exposure of the plants to the stress (50 DAS). It was noted that the reduction is mostly due to the increasing water salinity, but also due to the abscission of adult leaves, represented in Figure 4C. The obtained results agree with those reported by Santos et al. (2016), who also found a reduction in cotton leaf area with increasing water salinity. Lima et al. (2018) also observed reduction of leaf area in cotton plants cv. BRS Rubi subjected to salt stress and attributed such reduction to the decrease in cell volume, through the loss of turgor, because cell elongation and division directly depend on cell extensibility. In addition, reduction in LA is usually considered an important strategy to protect and/or acclimate plants to high salinity, eventually minimizing water losses through transpiration and maintaining a high cell water potential (Nascimento et al., 2011).

Plant height and leaf area significantly differed between the cotton cultivars. BRS Safira obtained higher value of plant height, and the difference was equal to $2.03 \mathrm{~cm}$ at $20 \mathrm{DAS}$ and to $7.29 \mathrm{~cm}$ at $50 \mathrm{DAS}$, compared to the cultivar BRS $368 \mathrm{RF}$ (Figure 4F). Similar result was obtained for cotton leaf area at 20 DAS (Figure 4G), since the cultivar BRS Safira reached the highest value $\left(138.33 \mathrm{~cm}^{2}\right)$ and the difference between the two

Table 2. Summary of the analysis of variance for plant height (PH), stem diameter (SD), leaf area (LA) and number of leaves (NL) of cotton cultivars irrigated with saline water, at 20 and 50 DAS

\begin{tabular}{|c|c|c|c|c|c|c|c|c|c|}
\hline \multirow{4}{*}{ Source of variation } & \multirow{4}{*}{ DF } & \multicolumn{8}{|c|}{ Mean squares } \\
\hline & & \multicolumn{2}{|c|}{ PH } & \multirow{2}{*}{\multicolumn{2}{|c|}{ SD }} & \multicolumn{2}{|c|}{ LA } & \multicolumn{2}{|c|}{ NL } \\
\hline & & \multicolumn{7}{|c|}{ Days after sowing (DAS) } & \\
\hline & & 20 & 50 & 20 & 50 & 20 & 50 & 20 & 50 \\
\hline Salinity level (SL) & 4 & $10.35^{\text {ns }}$ & $870.90^{\star *}$ & $0.35^{\mathrm{ns}}$ & $8.76^{\star \star}$ & $3337.98^{\star}$ & $2897143.45^{\star \star}$ & $0.27^{\mathrm{ns}}$ & $227.22^{\star \star}$ \\
\hline Linear regression & 1 & $13.61^{*}$ & $2898.02^{\star *}$ & $0.74^{\mathrm{ns}}$ & $33.07^{\star \star}$ & $10185.38^{\star}$ & $11139425.29^{\star \star}$ & $0.61^{\mathrm{ns}}$ & $858.05^{\star *}$ \\
\hline Quadratic regression & 1 & $3.22^{\text {ns }}$ & $9.20^{\text {ns }}$ & $0.22^{\mathrm{ns}}$ & $0.35^{\mathrm{ns}}$ & $2129.94^{\mathrm{ns}}$ & $253852.04^{\mathrm{ns}}$ & $8 \times 10^{-3 \mathrm{~ns}}$ & $46.28^{\text {ns }}$ \\
\hline Cultivar & 1 & $41.00^{* *}$ & $531.44^{*}$ & $0.386^{\mathrm{ns}}$ & $3.29^{\mathrm{ns}}$ & $7586.16^{\star \star}$ & $77388.88^{\text {ns }}$ & $0.02^{\mathrm{ns}}$ & $2.02^{\mathrm{ns}}$ \\
\hline Interaction (SL X Cultivar) & 4 & $1.55^{\mathrm{ns}}$ & $32.34^{\mathrm{ns}}$ & $0.16^{\text {ns }}$ & $0.29^{\mathrm{ns}}$ & $551.26^{\mathrm{ns}}$ & $19132.01^{\text {ns }}$ & $0.52^{\mathrm{ns}}$ & $14.40^{\text {ns }}$ \\
\hline Residue & 27 & & & & & & & & \\
\hline CV (\%) & & 15.31 & 20.98 & 17.51 & 16.99 & 25.09 & 24.80 & 10.87 & 23.36 \\
\hline
\end{tabular}

ns, " ", " Not significant. Significant at $\mathrm{p}<0.01$ and $\mathrm{p}<0.05$ probability by F test respectively; DF - Degrees of fredom 

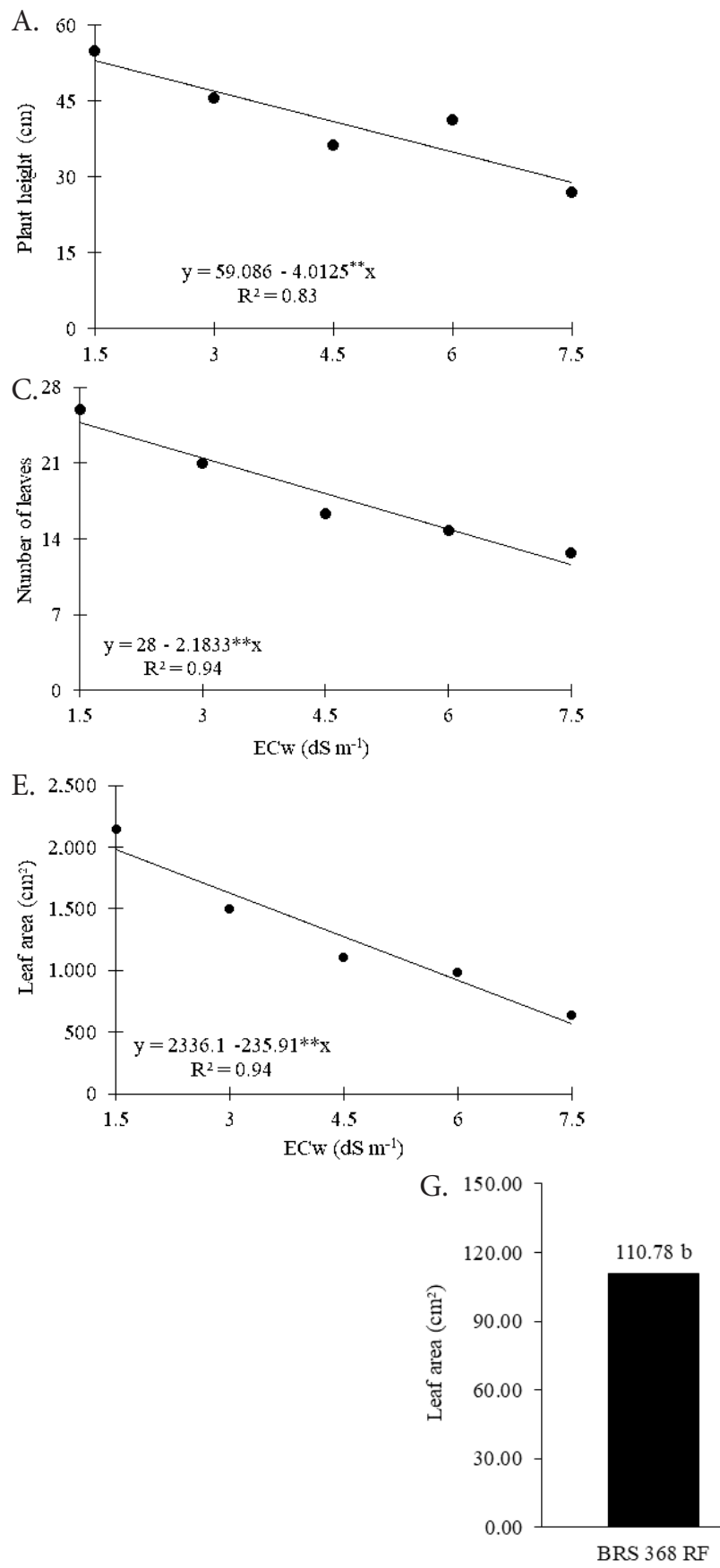
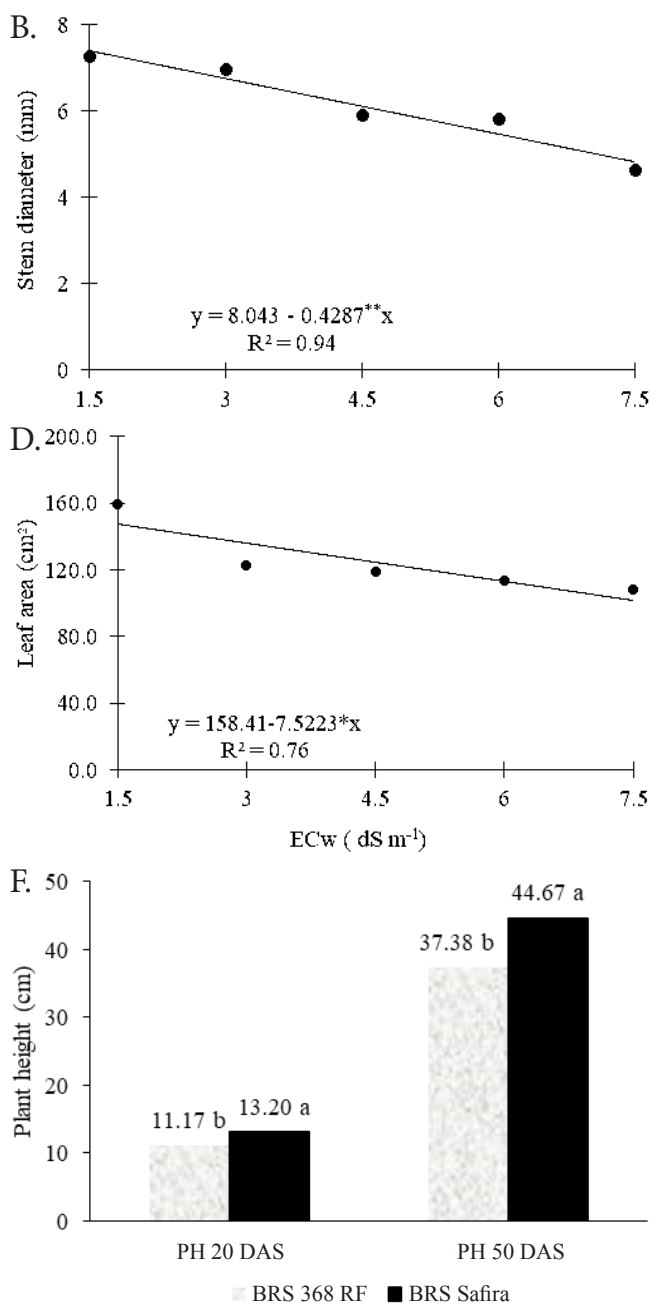

138.33 a

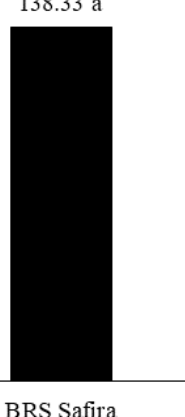

** - Significant at $\mathrm{p} \leq 0.01$, by F test; DAS - Days after sowing

Figure 4. Plant height - PH (A); stem diameter - SD (B); number of leaves - NL at 50 DAS (C) ; leaf area - LA at 20 (D) and at 50 DAS (E) as a function of water electrical conductivity - ECw; and plant height at 20 and 50 DAS (F) and leaf area at 20 DAS $(G)$ of cotton cultivars irrigated with different salinity water

cultivars was $27.55 \mathrm{~cm}^{2}$. According to the results, it is possible to state that the cultivar BRS 368 RF was more hampered by the exposure to salt stress in terms of $\mathrm{PH}$ and LA than the cultivar BRS Safira.

\section{Conclusions}

1. Increase in irrigation water salinity inhibited the vegetative growth and gas exchanges of the cotton cultivars BRS Safira and BRS 368 RF, and leaf area and instantaneous carboxylation efficiency are the most affected variables.

2. The cultivar BRS Safira has better physiological and growth performance when exposed to water salinity from 1.5 to $7.5 \mathrm{dS} \mathrm{m}^{-1}$, whereas the cultivar BRS $368 \mathrm{RF}$ is more affected by the salt stress.

\section{Literature Cited}

CONAB - Companhia Nacional de Abastecimento. 2018. Available on: <https://bit.ly/31da9hH>. Accessed on: Nov. 2018.

Donagema, G. K.; Campos, D. V. B. de; Calderano, S. B.; Teixeira, W. G.; Viana, J. H. M. (orgs.). Manual de métodos de análise de solo. 2.ed. Rio de Janeiro: Embrapa Solos, 2011. 230p. Documentos, 132

Ferreira, D. F. Sisvar: A guide for its bootstrap procedures in multiple comparisons. Ciência e Agrotecnologia, v.38, p.109-112, 2014. https://doi.org/10.1590/S1413-70542014000200001 
Freire, J. L. de O.; Dias, T. J.; Cavalcante, L. F.; Fernandes, P. D.; Lima Neto, A. J. de. Rendimento quântico e trocas gasosas em maracujazeiro amarelo sob salinidade hídrica, biofertilização e cobertura morta. Revista Ciência Agronômica, v.45, p.82-91, 2014. https://doi.org/10.1590/S1806-66902014000100011

Grimes, D. W.; Carter, L. M. A linear rule for direct nondestructive leaf area measurements. Agronomy Journal, v.3, p.477-479, 1969. https://doi.org/10.2134/agronj1969.00021962006100030048x

Jaimez, R. E.; Rada, F.; García-Núñez, C.; Azócar, A. Seasonal variations in leaf gas exchange of plantain cv. Hartón (Musa $\mathrm{AAB})$ under different soil water conditions in a humid tropical region. Scientia Horticulturae, v.104, p.79-89, 2005. https://doi. org/10.1016/j.scienta.2004.07.002

Konrad, M. L. F.; Silva, J. A. B. da; Furlani, P. R.; Machado, E. C. Trocas gasosas e fluorescência da clorofila em seis cultivares de cafeeiro sob estresse de alumínio. Bragantia, v.64, p.339-347, 2005. https:// doi.org/10.1590/S0006-87052005000300004

Larcher, W. Ecofisiologia vegetal. São Carlos: Rima Artes e Textos, 2006. 550p.

Lima, G. S. de; Dias, A. S.; Gheyi, H. R.; Soares, L. A. dos A.; Andrade, E. M. G. Saline water irrigation and nitrogen fertilization on the cultivation of colored fiber cotton. Revista Caatinga, v.31, p.151160, 2018. https://doi.org/10.1590/1983-21252018v31n118rc

Lima, G. S. de; Dias, A. S.; Soares, L. A. dos A.; Gheyi, H. R.; Camara Neto, J. P.; Oliveira, L. D. de. Cultivation of CNPA G3 sesame irrigated with saline water and fertilized with nitrate-N and ammonium-N. Revista Brasileira de Engenharia Agrícola e Ambiental, v.21, p.14-20, 2017a. https://doi.org/10.1590/18071929/agriambi.v21n1p14-20

Lima, G. S. de; Gheyi, H. R.; Nobre, R. G.; Soares, L. A. dos A.; Fernandes, P. D.; Furtado, G. de F. Trocas gasosas, pigmentos cloroplastídicos e dano celular na mamoneira sob diferentes composições catiônica da água. Irriga, v.22, p.757-774, 2017 b. https://doi.org/10.15809/irriga.2017v22n4p757-774

Medeiros, J. F. de. Qualidade de água de irrigação e evolução da salinidade nas propriedades assistidas pelo GAT nos Estados do RN, PB e CE. Campina Grande: UFPB, 1992. 173p. Dissertação Mestrado

Nascimento, S. P. do; Bastos, E. A.; Araújo, E. C. E.; Freire Filho, F. R.; Silva, E. M. da. Tolerance to water deficit of cowpea genotypes. Revista Brasileira de Engenharia Agrícola e Ambiental, v.15, p.853-860, 2011.

Neves, A. L. R.; Lacerda, C. F. de; Guimarães, F. V. A.; Hernandez, F. F. F.; Silva, F. B. da; Prisco, J. T.; Gheyi, H. R. Acumulação de biomassa e extração de nutrientes por plantas de feijãode-corda irrigadas com água salina em diferentes estádios de desenvolvimento. Ciência Rural, v.39, p.758-765, 2009. https:// doi.org/10.1590/S0103-84782009005000014
Novais, R. F.; Neves, J. C. L.; Barros, N. F. Ensaio em ambiente controlado. In: Oliveira, A. J. de; Garrido, W. E.; Araújo, J. D. de; Lourenço, S. (eds.). Métodos de pesquisa em fertilidade do solo. Brasília: Embrapa-SEA, 1991. p.189-253. Documentos, 3

Pereira, E. R. de L. Tolerância de genótipos de algodão colorido ao estresse salino. Campina Grande: UEPB, 2012. 105p. Dissertação Mestrado

Prisco, J. T.; Gomes Filho, E.; Miranda, R. de S. Physiology and biochemistry of plants growing under salt stress. In: Gheyi, H. R.; Dias, N. da S.; Lacerda, C. F. de; Gomes Filho, E. (eds.). Manejo da salinidade na agricultura: Estudos básicos e aplicados. Fortaleza: INCTSal, 2016. Cap.12, p.163-176.

Richards, L. A. Diagnosis and improvement of saline and alkali soils. Washington: U.S. Department of Agriculture, 1954. 160p. Agriculture Handbook, 60

Santos, J. B. dos; Gheyi, H. R.; Lima, G. S. de; Xavier, D. A.; Cavalcante, L. F.; Centeno, C. R. M. Morfofisiologia e produção do algodoeiro herbáceo irrigado com águas salinas e adubado com nitrogênio. Comunicata Scientiae, v.7, p.86-96, 2016. https://doi. org/10.14295/cs.v7i1.1158

Silva, E. N.; Ribeiro, R. V.; Ferreira-Silva, S. L.; Viégas, R. A.; Silveira, J. A. G. Comparative effects of salinity and water stress on photosynthesis, water relations and growth of Jatropha curcas plants. Journal of Arid Environments, v.74, p.1130-1137, 2010. https://doi.org/10.1016/j.jaridenv.2010.05.036

Sousa, A. E. C.; Silveira, J. A. G.; Gheyi, H. R.; Lima Neto, M. C.; Lacerda, C. F. de; Soares, F. A. L. Trocas gasosas e conteúdo de carboidratos e compostos nitrogenados em pinhão-manso irrigado com águas residuária e salina. Pesquisa Agropecuária Brasileira, v.47, p.1428-1435, 2012. https://doi.org/10.1590/S0100204X2012001000003

Souza, L. de P.; Nobre, R. G.; Barbosa, J. L.; Lima, G. S. de; Almeida, L. L. S.; Pinheiro, F. W. A. Cultivo do algodoeiro cv. BRS Topázio em solos salino-sódico com adição de matéria orgânica. Revista Espacios, v.38, p.18-29, 2017a.

Souza, L. de P.; Soares, L. A. dos A.; Lima, G. S. de; Nobre, R. G.; Gheyi, H. R.; Andrade, A. B. A. de. Adubação orgânica e águas de diferentes níveis salinos no cultivo do algodoeiro de fibra colorida. Revista Verde de Agroecologia e Desenvolvimento Sustentável, v.12, p.79-84, 2017b. https://doi.org/10.1590/S0100204X2012001000003

Taiz, L.; Zeiger, E.; Møller, I. M.; Murphy, A. Fisiologia e desenvolvimento vegetal. 6.ed. Porto Alegre: Artmed, 2017. 888p.

Tavares Filho, A. N.; Barros, M. de F. C.; Rolim, M. M.; Silva, Ê. F. de F. e. Incorporação de gesso para correção da salinidade e sodicidade de solos salino-sódicos. Revista Brasileira de Engenharia Agrícola e Ambiental, v.16, p.247-252, 2012. https://doi.org/10.1590/S141543662012000300002 